\title{
Fuzzy Optimization Method In The Search And Determination of Scholarship Recipients Systems at The University
}

\author{
Nurdin \\ Department of Informatics \\ Universitas Malikussaleh \\ Aceh Utara, Indonesia
}

\begin{abstract}
Decision support system is an interactive system to support decision-making process through the alternatives derived from the processing of data, information and design models. In this research will build a decision support system modeling for the determination of admission scholarship, as long as this problem of determining admission scholarship often become obstacles in distribution and is not directed at the destination as expected. Therefore, in order to give a better result and overcome obstacles in the distribution of scholarships. The problems of determining admission scholarship will be resolved through Fuzzy approach to the Analytic Hierarchy Process (AHP) is modeled in a decision support system modeling. Where Fuzzy will perform the functions of representation based membership in the assessment criteria. So the results given Fuzzy will be approached with the weight vector given by the Analytic Hierarchy Process (AHP) which would then be carried out by the ranking process Analiytic Hierarchy Process (AHP) to determine the best alternative will be selected as scholarship recipients. After Fuzzy AHP approach in modeling decision support systems, particularly in the determination of admission scholarships and given very good results and focus on the goal as expected.
\end{abstract}

Keywords: scholarship, education, optimization, fuzzy method, tracer.

\section{INTRODUCTION}

Decision support system is an interactive system in support of the decision making process through alternative obtained from the processing of data, information and design models ${ }^{1}$. Decision-making is needed to accelerate the process of achieving a more focused goal. Decision support system has been widely used to resolve problems within an organization. Because the decision support system is considered capable of helping to solve any problems and provide better results. The concept of decision support systems are often used to solve the problem, because the decision support system is considered capable of giving a good decision in resolving the issue $^{2}$. Many decision support system used to resolve problems using method such as topsis, Simple Additive Weighting (SAW) and Weight Product for grading problems with the aim to get the best alternative will be selected through a decision support system. That problem has been solved in many different cases with good results.

So far, the problem of determining admission scholarship often become obstacles in distribution and is not focused on the goal as expected, that the settlement is often solved using decision support systems ${ }^{3}$. To provide a good change and focused on the goals, especially in the determination of admission scholarship, is expected to give a good result and more efficiently through a decision support system. To give a good result, researchers will make a change to build a decision support system modeling approach to the fuzzy Analytic Hierarchy Process (AHP) to resolve the problem of determining admission scholarships through the assessment criteria of each alternative to determine the scholarship recipients.

Fuzzy set theory is a mathematical framework used for the present uncertainty, ambiguity, inaccuracy, lack of information and partial truth (Tettamanzi, 2001). While the Analytic Hierarchy Process (AHP) is a method to process multiple criteria complex problem into a hierarchical model (Warston school, 1970). Hierarchy is defined as a representation of a complex problem into a multi-level structure, where the first level is the goal, which is followed by the level of criteria, sub-criteria, and so on down to the last level is an alternative level ${ }^{5}$.

In this study, will be developed a decision support system modeling is static on the assessment criteria with fuzzy approach and Analytic Hierarchy Process (AHP) in determining admission scholarship. The research conducted to determine the extent of change for the better given by the decision support system modeling approach to the fuzzy Analytic Hierarchy Process (AHP) in the evaluation of each criterion, so that with the decision support system modeling with fuzzy $\mathrm{AHP}^{4}$, especially in the assessment criteria a criteria of each alternative to determine the best alternative would have been able to give a good result as expected.

\section{METHODOLOGY}

Build a decision support system modeling with fuzzy and Analytic Hierarchy Process (AHP) in determining admission scholarship it is necessary to provide a modeling as in figure 1 . 
International Journal of Computer Applications Technology and Research

Volume 4- Issue 7, 512 - 516, 2015, ISSN:- 2319-8656

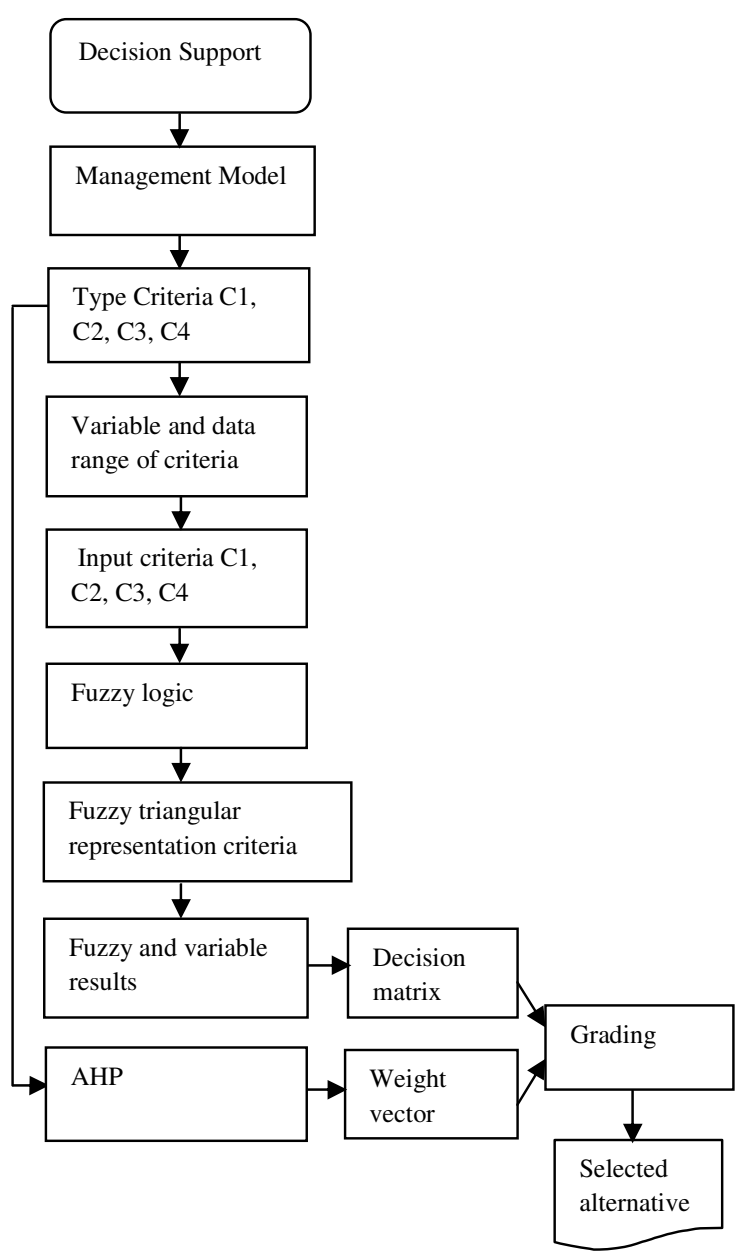

Figure 1. Model system in determining admission scholarship

The criteria will be assessed in determining acceptance of the scholarship are: criteria GPA (C1), parental income (C2), a dependent parent (C3) and distance (C4). Based on the criteria assessed, the decision support will form a decision on any criteria table with the number of alternatives that will be tested are six alternatives ${ }^{6}$, as Table 1 below:

Table 1. Decisions on each criterion for each alternative

\begin{tabular}{|c|l|l|c|c|}
\hline & \multicolumn{4}{|c|}{ Criteria } \\
\hline $\begin{array}{l}\text { Alternat } \\
\text { ive }\end{array}$ & GPA & $\begin{array}{l}\text { Parental } \\
\text { income }\end{array}$ & $\begin{array}{l}\text { Dependent } \\
\text { parents }\end{array}$ & Distance \\
\hline $\mathrm{A}_{1}$ & 3.00 & 1.500 .000 & 2 & 10 \\
\hline $\mathrm{A}_{2}$ & 3.50 & 1.300 .000 & 6 & 20 \\
\hline $\mathrm{A}_{3}$ & 3.30 & 2.000 .000 & 4 & 16 \\
\hline $\mathrm{A}_{4}$ & 3.00 & 3.600 .000 & 6 & 20 \\
\hline $\mathrm{A}_{5}$ & 3.80 & 1.500 .000 & 4 & 23 \\
\hline $\mathrm{A}_{6}$ & 3.65 & 2.000 .000 & 3 & 7 \\
\hline
\end{tabular}

\section{The first Pase:}

At first this pase, decision support will apply the concept of work of the fuzzy, fuzzy which would give preference to the assessment criteria $\mathrm{C} 1, \mathrm{C} 2, \mathrm{C} 3, \mathrm{C} 4$ which will be represented using triangular fuzzy ${ }^{7}$, as in following table through IV below:

a. Criteria GPA (C1)

Table 2. Criteria GPA

\begin{tabular}{|l|l|}
\hline variables & The range of data GPA \\
\hline low & {$[0-2.90]$} \\
\hline moderate & {$[2.70-3.20]$} \\
\hline high & {$[3.00-4.00]$} \\
\hline
\end{tabular}

b. Criteria income parents $(\mathrm{C} 2)$

Table 3. Criteria income parents

\begin{tabular}{|l|l|}
\hline variables & The range of parental income data \\
\hline low & $3.500 .000-6.000 .000$ \\
\hline moderate & $1.500 .000-4.000 .000$ \\
\hline high & $0-2.000 .000$ \\
\hline
\end{tabular}

c. Criteria dependent parents (C3)

Table 4. Criteria dependent parents

\begin{tabular}{|l|l|}
\hline variables & The range of data dependent parents \\
\hline low & {$[1-3]$} \\
\hline moderate & {$[2-5]$} \\
\hline high & {$[4-7]$} \\
\hline
\end{tabular}

d. Criteria distance (C4)

Table 5. Criteria distance

\begin{tabular}{|l|l|}
\hline variables & The range of distance data. \\
\hline low & {$[0-10]$} \\
\hline moderate & {$[6-15]$} \\
\hline high & {$[11-30]$} \\
\hline
\end{tabular}

Based on the table above criteria and the range of existing data in each table, the next support will make a decision using fuzzy triangular representation for each assessment criteria on $\mathrm{C} 1, \mathrm{C} 2, \mathrm{C} 3, \mathrm{C} 4$, namely;

Triangular fuzzy representation can be seen in figure 2 :

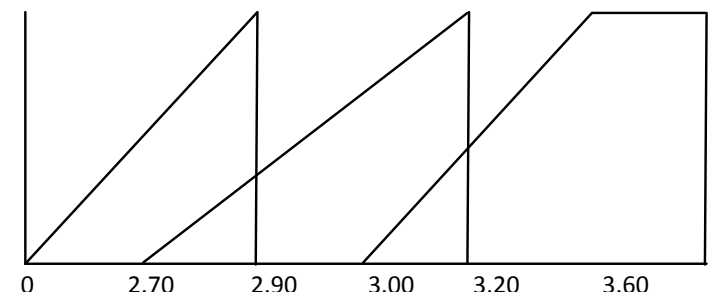

Figure 2. Representation of fuzzy triangles for GPA criteria Membership functions for each of the criteria set GPA can be given as follows ${ }^{9}$ : 
International Journal of Computer Applications Technology and Research

Volume 4- Issue 7, 512 - 516, 2015, ISSN:- 2319-8656

$$
\begin{aligned}
& \text { Low }\left\{\begin{array}{l}
0 ; x \leq 0 \\
\frac{x}{2.90} ; 0<x \leq 2.90 \\
1: x=2.90
\end{array}\right. \\
& \text { Moderate }\left\{\begin{array}{l}
0 ; x \leq 2.70 \\
\frac{x-2.70}{3.20-2.70} ; 2.70<x \leq 3.20 \\
1 ; x=3.20
\end{array}\right. \\
& \text { High }\left\{\begin{array}{l}
0 ; x \leq 3.00 \\
\frac{x-3.00}{3.60-3.00} ; 3.00<x \leq 3.60 \\
1 ; 360 \leq \mathrm{x} \leq 4.00
\end{array}\right.
\end{aligned}
$$

For the next triangular fuzzy representations made on the criteria of parental income, dependent parents and distance in order to obtain the membership function of each criterion.

\section{The second phase:}

While in the second phase, decision support will give preference based on (Cheng, 1999) which direpsentasikan triangular fuzzy parameters $u \_i, \alpha \_i, \beta \_i$ can be categorized as follows ${ }^{11}$ :

$$
\begin{array}{ll}
\text { Very high } & =(1 ; 0,8 ; 1) \\
\text { High } & =(0,75 ; 0,6 ; 0,9) \\
\text { Moderate } & =(0,5 ; 0,3 ; 0,7) \\
\text { Low } & =(0,25 ; 0,05 ; 0,45) \\
\text { Very low } & =(0 ; 0 ; 0,2)
\end{array}
$$

Alternatives to - 1

$\mathrm{C} 1=$ Results triangular fuzzy representation $=0,6$

Variable $=$ moderate $(0,3 ; 0,18 ; 0,42)$

$\mathrm{C} 2=$ Results triangular fuzzy representation $=1$

Variable $=$ Moderate $(0,5 ; 0,3 ; 0,07)$

$\mathrm{C} 3=$ Results triangular fuzzy representation $=0,5$

Variable $=$ Low $(0,125 ; 0,025 ; 0,225)$

$\mathrm{C} 4=$ Results triangular fuzzy representation $=1$

Variable $=$ Low $(0,25 ; 0,05 ; 0,45)$

Alternatives to -2

$\mathrm{C} 1=$ Results triangular fuzzy representation $=0,833$

Variable $=\operatorname{High}(0,625 ; 0,499 ; 0,749)$

$\mathrm{C} 2=$ Results triangular fuzzy representation $=0,7$ Variable $=\operatorname{High}(0,525 ; 0,42 ; 0,63)$

$\mathrm{C} 3=$ Results triangular fuzzy representation $=1$ Variable $=\operatorname{High}(0,75 ; 0,6 ; 0,9)$

$\mathrm{C} 4=$ Results triangular fuzzy representation $=0,642$

Variable $=\operatorname{High}(0,482 ; 0,386 ; 0,578)$

Based on the above parameters, parameter values taken by the decision support for the assessment of each criterion $\mathrm{C} 1, \mathrm{C} 2$, $\mathrm{C} 3, \mathrm{C} 4$ is low $(0.25 ; 0.05 ; 0.45)$, moderate $(0.5 ; 0.3 ; 0,7)$ and high $(0.75 ; 0.6 ; 0.9)$. The results of triangular fuzzy representation in $\mathrm{C} 1, \mathrm{C} 2, \mathrm{C} 3, \mathrm{C} 4$ and every value that is given to the criteria $\mathrm{C} 1, \mathrm{C} 2, \mathrm{C} 3, \mathrm{C} 4$ and after adjusting the value of the parameter that is; low, medium and high, then the results are given for each alternative are as follows:

Results of triangular fuzzy representation for dependents of parents and distance criteria is also given as two alternatives above, so that under any of these alternatives ${ }^{10}$, decision support will form a decision matrix as follows:

$$
\mathrm{K}=\left[\begin{array}{llll}
0,3 & 0,5 & 0,125 & 0,25 \\
0,625 & 0,525 & 0,75 & 0,482 \\
0,375 & 0,4 & 0,333 & 0,268 \\
0,3 & 0,24 & 0,75 & 0,482
\end{array}\right]
$$

\section{The third Phase}

While in the third phase, the next decision support will use Analytic Hierarchy Process (AHP) to determine the level of importance of each criterion in order to obtain the weight vector. Where Analytic Hierarchy Process (AHP) will determine the scale ratio of 1-9 for each criterion $\mathrm{C} 1, \mathrm{C} 2, \mathrm{C} 3$, C4. The scale of this comparison are in Table 6.

Table 6. Importance Criteria

\begin{tabular}{|l|c|l|}
\hline scale & Pair & Information \\
\hline 1 & 1 & equally important \\
\hline 3 & $\frac{1}{3}$ & $\begin{array}{l}\text { Somewhat more important that one } \\
\text { with the other }\end{array}$ \\
\hline 5 & $\frac{1}{5}$ & quite important \\
\hline 7 & $\frac{1}{7}$ & Crucial \\
\hline 9 & $\frac{1}{9}$ & Absolutely more important \\
\hline $2,4,6,8$ & $\frac{1}{2} \frac{1}{4} \frac{1}{6} \frac{1}{8}$ & The median \\
\hline
\end{tabular}

In Table 6 above, a table of the level of importance for each criterion will be assessed against four criteria previously set by the decision support that is GPA (C1), parental income (C2), a dependent parent (C3) and distance (C4). The below shows the stages - steps being taken Analytic Hierarchy Process (AHP) to obtain the weight vector:

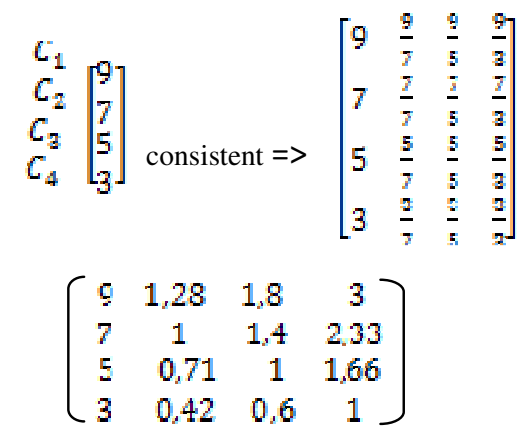

number $24 \quad 3,41 \quad 4,8 \quad 7,99$ 
International Journal of Computer Applications Technology and Research

Volume 4- Issue 7, 512 - 516, 2015, ISSN:- 2319-8656

After normalization becomes:

Then the value of the weight vector obtained:

$$
\mathrm{W}=[0,375 ; 0,291 ; 0,207 ; 0,124]
$$

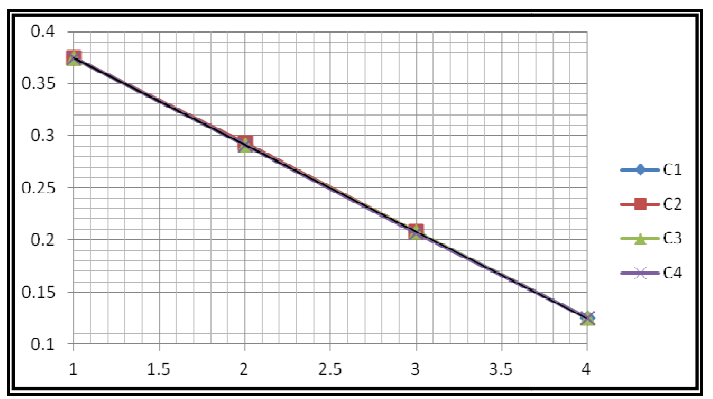

Figure 3. graphs of normality

After the weight vector is obtained, then a decision support will determine which alternative will be chosen, where the weight vector will be summed with the decision matrix using the following equation:

$$
s_{j}=\sum_{i}\left(s_{i j}\right)\left(w_{i}\right)
$$

$\mathrm{S} 1=(0,3 * 0,375)+(0,5 * 0,291)+(0,125 * 0,207)+$

$$
(0,25 * 0,124)=0,314875
$$

$\mathrm{S} 2=(0,625 * 0,375)+(0,525 * 0,291)+(0,75 * 0,207)+$ $(0,482 * 0,124)=0,602168$

$\mathrm{S} 3=(0,375 * 0,375)+(0,4 * 0,291)+(0,333 * 0,207)+$

$(0,268 * 0,124)=0,359239$

$\mathrm{S} 4=(0,3 * 0,375)+(0,24 * 0,291)+(0,75 * 0,207)+$

$(0,482 * 0,124)=0,397376$

$\mathrm{S} 5=(0,75 * 0,375)+(0,5 * 0,291)+(0,333 * 0,207)+$ $(0,643 * 0,124)=0,575464$

S6 $=(0,75 * 0,375)+(0,4 * 0,291)+(0,25 * 0,207)+$ $(0,175 * 0,124)=0,471100$

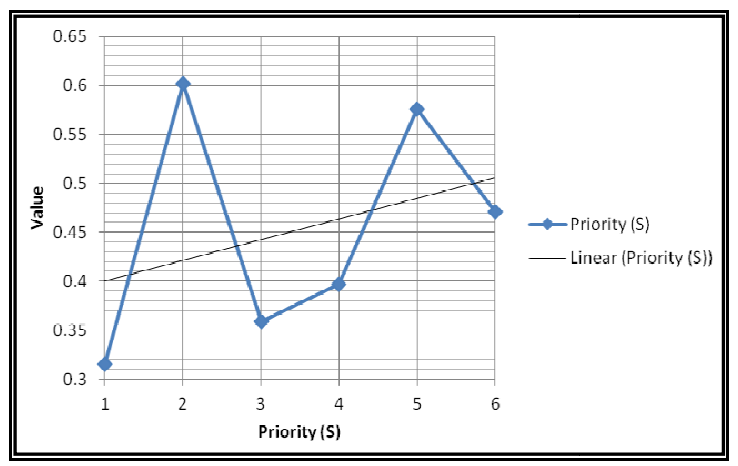

Figure 4. Decision matrix

After the grading of the six alternatives based on four criteria $^{12}$ : assessment GPA (C1), parental income (C2), a dependent parent (C3) and distance (C4), the alternative chosen is an alternative that has the highest value is $\mathrm{S} 2=$ 0.602168 .

\section{RESULTS AND DISCUSSION}

\subsection{RESULTS}

As for the implementation phase describes the results of a discussion of the results and fuzzy approach in modeling decisions with Analytic Hierarchy Process (AHP) to be given very good results. As the display using the programming language $\mathrm{C}++$ is shown below:

1) Display alternative input

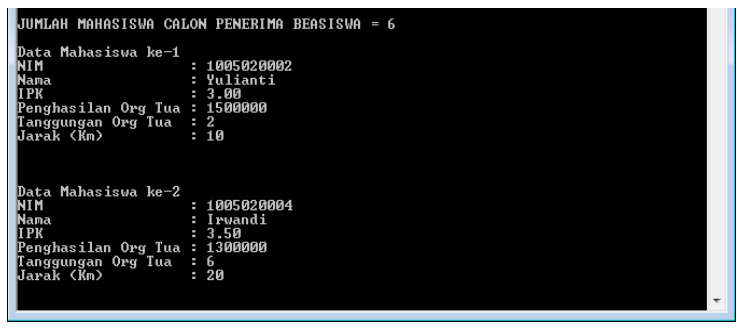

Figure 5. Display alternative input Tampilan

In Figure 5 above is a view of an alternative input to the data examined, namely 6 alternative. While the data are assessed at each alternative is GPA (C1), parental income (C2), a dependent parent (C3) and distance (C4). As for nim and the name is only used as information to distinguish one alternative to other alternatives.

2) Display output decision matrix

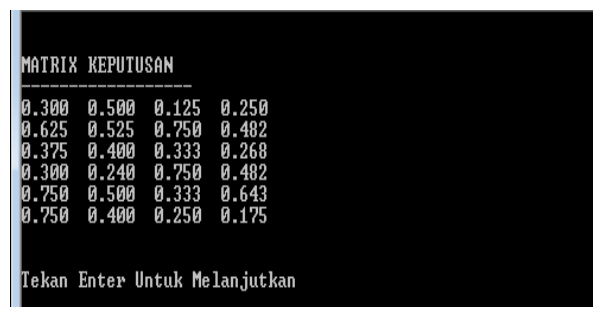

Figure 6. Display output decision matrix

Based on the above picture 6 , of the two alternatives that have been previously inputted and selected, before the final results are given through the rankings, the first determination of the applicants program gives a result that is a decision matrix. Wherein the decision matrix is obtained based on the input values such as GPA (C1), parental income (C2), a dependent parent $(\mathrm{C} 3)$ and distance $(\mathrm{C} 4)$, which previously represented by triangular fuzzy.

3) Display output of ranking results

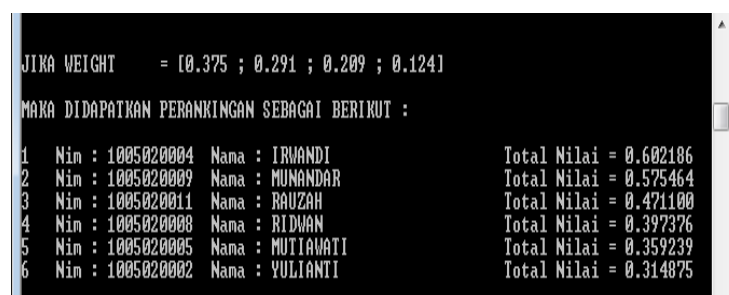


Figure 7. Display output of ranking results

While in figure 7 above, is the final result given by the program determination of the applicants. As contained in the above image display program, is the end result after the decision matrix is obtained. At the end of this program describes the ranking process using Analytic Hierarchy Process (AHP).

\subsection{DISCUSSION}

In this study, related to the fuzzy approach in modeling support system with Analiytic Hierarcy Process for the settlement of the problem through the assessor criteria that is chosen is GPA (C1), parental income (C2), a dependent parent (C3) and distance (C4). Particularly in this discussion after the authors analyze and implements in the $\mathrm{C}++$ programming language, it is given very good results of modeling decision support system in determining which alternative will be chosen based on the rank. Decision support in handling the problem through any assessment criteria selected criteria and the stage of completion is resolved and routed through a fuzzy, in which fuzzy in giving preference through assessment criteria $\mathrm{C} 1, \mathrm{C} 2, \mathrm{C} 3, \mathrm{C} 4$ are represented using triangular fuzzy. Decision support based on the results of a given triangle fuzzy representation and after adjusting the parameters, the next support will form a decision-making matrix. Where the latter matrix, the decision will be approached with the weight vector given by AHP.

Decision support also use Analytic Hierarchy Process (AHP) in determining the level of importance of each criterion GPA (C1), parental income $(\mathrm{C} 2)$, a dependent parent (C3) and distance (C4) in order to obtain a weight vector based matrices and after normalization, then obtained a weight vector that weight $[0.375 ; 0.291 ; 0.207 ; 0.124]$, as shown in the figure above 6 . After the weight vector is obtained, then the AHP will do the rankings is through the sum of the weight vector by a matrix decision with the aim of better results given in determining the alternative will be selected, as the output of the results of the rankings contained in Figure 5 above.

\section{CONCLUSIONS}

In this study, the result looks better given through a fuzzy approach to modeling decision support systems through the assessment criteria of GPA (C1), parental income (C2), a dependent parent (C3) and distance (C4) presented with triangular fuzzy and processes a ranking conducted by Analytic Hierarchy Process (AHP) to determine the best alternative will be selected.

\section{REFERENCES}

[1] Daihani, D.Y."Sistem Pendukung Keputusan”, Elex Media Komputindo Jakarta, 2001.

[2] Turban. "Decision support systems and intelligent system (Sistem Pendukung Keputusan dan Sistem Cerdas)", Edisi 7 Jilid 1. Andi, Yogyakarta, 2005.

[3] Saaty,T.L. "Decision Making With The Analytic Hierarchy Process", Int. J. Services Sciences, pp. 83 - 98, 2008.

[4] Turban \& Efraim, J.E. "Decision support systems and intelligent system-sevent edition", New Delhi, Prentice Hall of India, 2007.

[5] Cheng, C.H., Yang, K.L. \& Hwang, C.L. "Evaluating attack helocopters by AHP based on linguistic variable weight" Dordrecht, 1999.

[6] Anshori, Y." Pendekatan triangular fuzzy number dalam metode analiytic hierarcy proses". Jurnal Ilmiah Foristek, 2012.

[7] Eniyati, S. "Perancangan sistem pendukung pengambilan keputusan untuk penerimaan beasiswa dengan metode SAW", Jurnal teknologi informasi dinamik, pp. 171 - 176, 2011.

[8] Jijun, Z. " Fuzzy analytic hierarchy process", A Chinese Journal of Fuzzy systems and math-ematics, pp.14: 81-89, 1999.

[9] Kong, F \& Liu, H. "Applying Fuzzy Analytic Hierarchy Process To Avaluate Success Factors Of E-Commerc", International Journal of Information and Systems sciens, pp.406 - 412, 2005.

[10] Lootma \& Freek A. "Fuzzy logic for planning and decision making. Kluwer Academic Publissher, Netherlends, 1997.

[11] Reenoij, S. "Multi attribute decision making under Certainty", The Analytic Hierarchy Process, 2005.

[12] Tettamanzi, A \& Tomassini, M. "Soft computing integrating evalutionary, Neural and fuzzy systems", Springer-verlag, Berlin, 2001. 